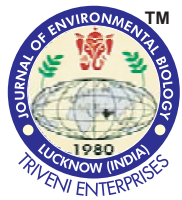

DOI : http://doi.org/10.22438/jeb/39/2/MRN-341

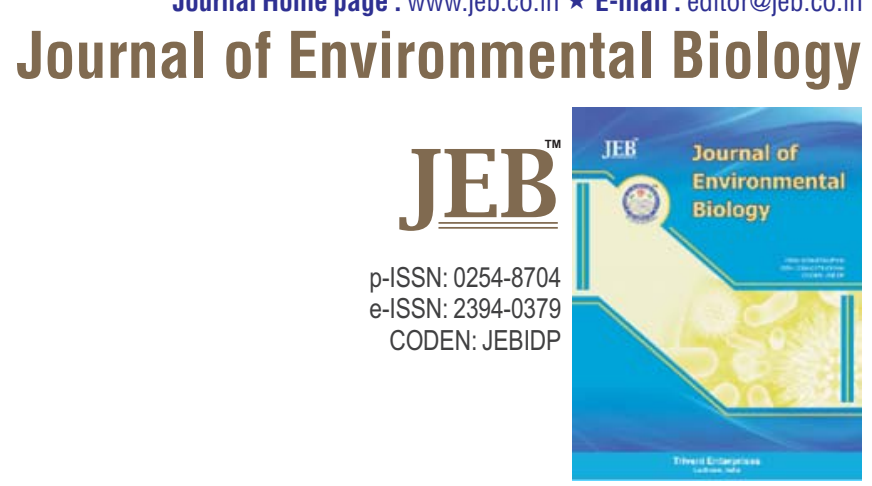

\title{
Antioxidant and antimicrobial properties of seed oil of Datura metel
}

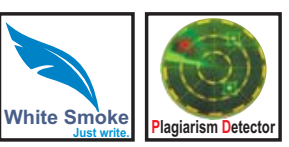

Authors Info

R.K. Bachheti', I. Rai', V.K. Mishra $^{2 *}$ and A. Joshi ${ }^{3}$

'Department of Chemistry, Graphic Era University, Dehradun-248 002, India

'Department of Biotechnology, Doon P.G. Paramedical College, Dehradun-248 991, India

${ }^{3}$ Department of Environmental Science, Graphic Era University, Dehradun-248 002, India

${ }^{*}$ Corresponding Author Email : mishravkbhu@gmail.com

Key words

Antioxidant Antimicrobial activity Datura metel Seed oil

Publication Info

Paper received : 23.05.2016 Revised received : 29.11.2016

Re-revised received : 16.03.2017 Accepted : 23.03.2017

\section{Abstract}

Aim : Dature metel is a valuable medicinal plant in traditional and contemporary systems of medicines in India, China and Africa. The present study aimed to evaluate antioxidant and antimicrobial properties of seed oil of Datura metel.

Methodology : The seeds of $D$. metel were extracted in Soxhlet apparatus with petroleum ether. The seed oil obtained was used for assessing the antioxidant capacity using radical scavenging (DPPH and nitric oxide) and reducing power. The antimicrobial potential of seed oil was assessed by agar diffusion and microdilution methods.

Results : The $\mathrm{IC}_{50}$ of seed oil for nitric oxide radical scavenging was at par with standard antioxidant, curcumin $\left(88 \mu \mathrm{g} \mathrm{ml}^{-1}\right.$ and $80 \mu \mathrm{g} \mathrm{ml}^{-1}$ ) The reducing power ability of oil was higher than the reference ascorbic acid ( $\mathrm{IC}_{50} 8$ and $22 \mu \mathrm{g} \mathrm{ml}^{-1}$ ). The study also showed significant antibacterial and anticandidial activities of seed oil.

Interpretation : Seed oil of Datura metel exhibited significant antioxidant and antimicrobial activities.
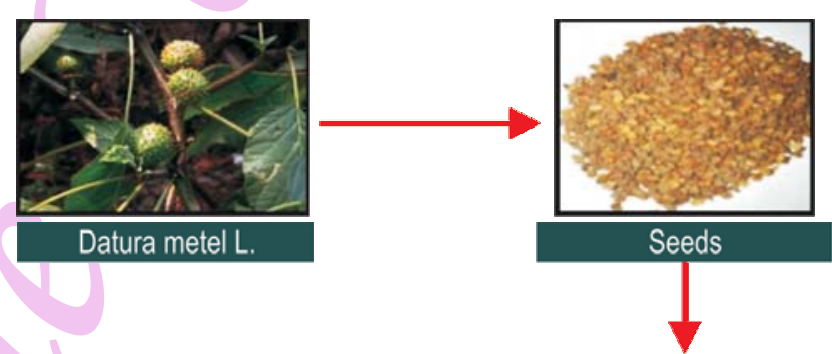

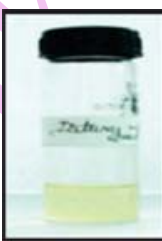

Seeds oil
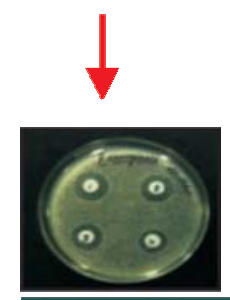

Antimicrobial activity

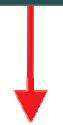

- Probiotic microorganism : Lactobacillus plantarum and Lactobacillus delbrueckii subsp. lactis

- Pathogenic bacteria : Staphylococcus aureus subsp. aureus, Salmonella typhi, Shigella flexneri, Vibrio vulnificus, Psuedomonas aeruginosa

- Opportunistic fungal pathogens : Candida albicans 


\section{Introduction}

The genus Datura belongs to family solanaceae comprise of nine species. The term Datura is derived from Sanskrit Dustura or Dahatura (Mann, 1996). Datura metel is a wild growing shrub. The alkaloids present in solanaceae plants have been an age old source of herbal anticholinergic drugs, scopolamine and hyosciamine (Alebiowu et al., 2007; Gaire and Subedi, 2013), but their overdose and concurrent use may cause toxicity. Almost all parts of Datura metel including seeds, seed oil, flower and leaves find applications in traditional medicine (Duke and Ayensu, 1985; Maheshwari et al., 2013). Previous studies on extracts of Datura metel have reported many phytochemicals such as alkaloids, flavonoids, phenols, saponins, sterols and tannins (Donatus and Ephraim, 2009). A growing body of evidence suggest that Datura metel extract possess antioxidant (Alabri et al., 2014; Roy et al., 2016), antibacterial (Hossain et al., 2014; Akharaiyi 2011), antifungal ; (Rajesh and Sharma, 2002; Dabur et al., 2005), anti-proliferative and immunosuppressive properties (Bellila et al., 2011; Yang et al., 2014). In contrast, very little is known about seed oil of Datura metel.

The lesser known oilseeds including Datura metel represent untapped resource for lipids that otherwise would go waste if not utilized properly. Recently, there has been growing interest in antioxidants and antimicrobial property of these plants (Ozcan et al., 2010; Atanasov et al., 2015; Pawar et al., 2017). A number of researchers have reported antioxidant and antimicrobial potential of seed oil from some plants such as apple (Cervantes-Cardoza et al., 2010, Tian et al., 2010), black cumin (Nair et al., 2005), basil (Hussain et al., 2008), grape (Garavaglia et al., 2016), olive (Rigacci and Stefani, 2016), Pongamia (Sajid et al., 2012), pumpkin (Nawirska-Olszańska et al., 2013), sesame (Borjian et al., 2016) etc. The seed oil of Datura metel is rich in polyunsaturated fatty acids, lipid soluble antioxidants and polyphenols (Ramadan et al., 2009). So far antioxidant and antimicrobial properties of seed oil of Datura metel has not been comprehensively studied. Therefore, the aim of the present investigation was to assess antioxidant and antimicrobial properties of seed oil of Datura metel.

\section{Materials and Methods}

Plant material : Datura metel seeds of were collected from the Dugadda forest (latitude $29^{\circ} 48^{\prime} 25.04 " \mathrm{~N}$ and longitude $78^{\circ} 36^{\prime} 33.74^{\prime \prime E}$ ), Uttarakhand (India). Firstly, the seeds were dried with in shade for 14 days, then oven-dried at $40^{\circ} \mathrm{C}$ for $48-72 \mathrm{hrs}$. The dried seeds were powdered in a blender, sieved through 1 $\mathrm{mm}$ mesh screen and soxhlet extracted using petroleum ether for $8 \mathrm{hrs}$. Subsequently, the solvent was kept off using rotary evaporator at $40^{\circ} \mathrm{C}$ under reduced pressure. Seed oil was then collected in capped tubes and refrigerated at $4^{\circ} \mathrm{C}$ for further study.

Microorganism and growth media : The microbial pathogens, Gram-positive bacteria: Lactobacillus delbrueckii subsp lactis
MTCC 911, Lactobacillus plantarum MTCC 2621, Staphylococcus aureus MTCC 737 and Gram-negative bacteria: Escherichia coli MTCC 443, Pseudomonas aeruginosa MTCC 424, Salmonella typhi MTCC 531, Shigella flexneri MTCC 1457, Vibrio vulnificus MTCC 1145; and the Candida species, Candida albicans MTCC 227 and Candida tropicalis MTCC 230 were procured from microbial type culture collection (MTCC), Chandigarh, India and stored on agar slants at $4^{\circ} \mathrm{C}$ in a refrigerator until further use.

DPPH radical scavenging activity : DPPH free radical scavenging activity of seed oil of Datura metel was assessed following the method of Cuendet et al. (1997). The reaction consisted of $0.5 \mathrm{ml}$ of oil samples $\left(10-1000 \mu \mathrm{gmll}^{-1}\right), 2.5 \mathrm{ml}$ of distilled water and $3 \mathrm{ml} \mathrm{DPPH}(0.1 \mathrm{mM})$ in ethanol. The resulting solution was kept for 30 min in dark at room temperature. Following this, the absorbance of solution was recorded at 517 $\mathrm{nm}$ against control (ethanolic DPPH without any sample/ or standard). Curcumin was used as reference. The percent DPPH free radical scavenging was calculated by comparing the absorbance of control and test sample.

Nitric oxide radical scavenging activity : Sodium nitroprusside (SNP) initiates spontaneous formation of nitric oxide in solution at physiological pH (Marcocci et al., 1994) that on reacting with oxygen forms nitrite ions which was measured by Griess Illosvoy reaction (Garrat, 1964). Two millilitre sodium nitroprusside (SNP) $(10 \mathrm{mM})$ in phosphate buffer saline (PBS) $(0.5 \mathrm{mM}, \mathrm{pH} 7.4)$ was aliquoted into $0.5 \mathrm{ml}$ of seed-extract $\left(10-1000 \mu \mathrm{gml}^{-1}\right.$, prepared in ethanol) and incubated at $25^{\circ} \mathrm{C}$ for $2 \mathrm{hrs}$. After incubation, $0.5 \mathrm{ml}$ of extract was mixed with $0.5 \mathrm{ml}$ of Griess reagent. The absorbance of the chromophore was measured at $540 \mathrm{~nm}$ against control (10 mM SNP in PBS without seed-extract/ or standard). Here in the assay, curcumin was used as reference. The percent inhibition of nitric oxide was measured by comparing the absorbance of control and test sample.

Potassium ferricyanide reducing power assay : The $\mathrm{Fe}^{3+}$ reducing power of the extract was determined following Oyaizu (1986). $0.1 \mathrm{ml}$ of seed oil of Datura metel $\left(10-1000 \mathrm{\mu gml}^{-1}\right)$ was mixed with $2.5 \mathrm{ml}$ potassium ferricyanide $(1 \% \mathrm{w} / \mathrm{v})$ and $2.5 \mathrm{ml}$ phosphate buffer $(0.2 \mathrm{M}, \mathrm{pH} 6.6)$. The resulting solution was incubated in a water bath at $50^{\circ} \mathrm{C}$ for $20 \mathrm{~min}$. The reaction was stopped with $2.5 \mathrm{ml}$ of $10 \%$ trichloroacetic acid. Thereafter, the solution was centrifuged at $4000 \mathrm{rpm}$ for $10 \mathrm{~min}$. A $2.5 \mathrm{ml}$ supernatant was mixed with equal volume of distilled water and then $0.5 \mathrm{ml}$ of $0.1 \%$ ferric chloride was immediately added to the above solution. The absorbance was measured at $700 \mathrm{~nm}$. Ascorbic acid was used as positive control.

Agar diffusion method : Assessment of antimicrobial potential of seed oil of Datura metal was carried out by using agar diffusion method as recommended by clinical and laboratory standards institute-approved standard (CLSI), CLSI M02-A11 and CLSI M27-A2. Amikacin $(10 \mu \mathrm{g})$ was used as standard antibiotic for 
A.

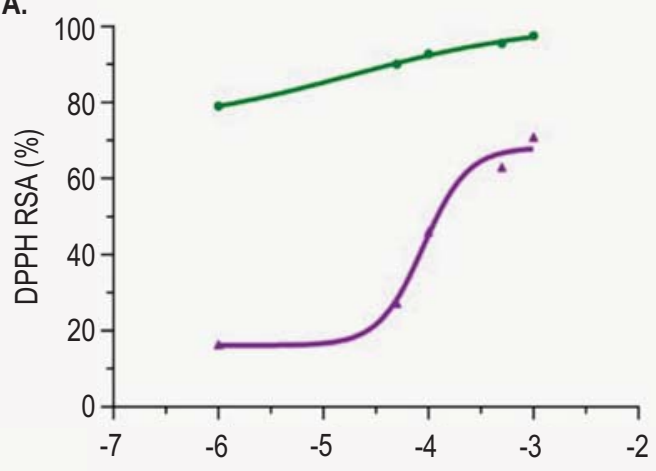

Log concentration

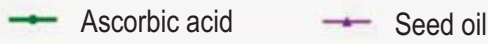

B.

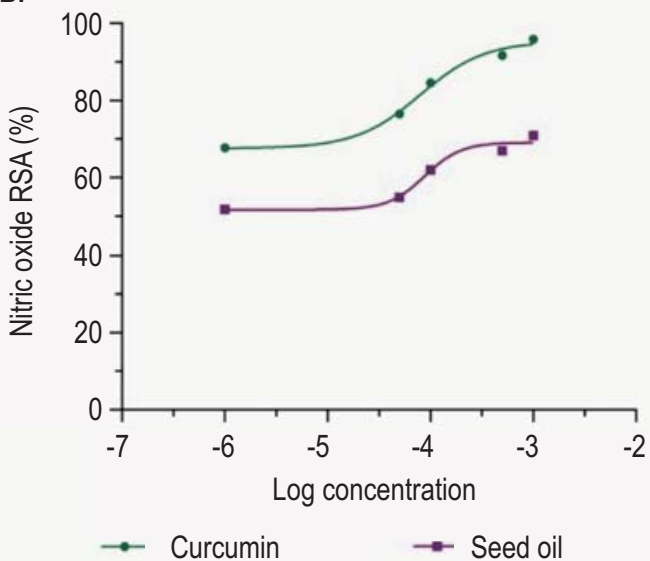

C.

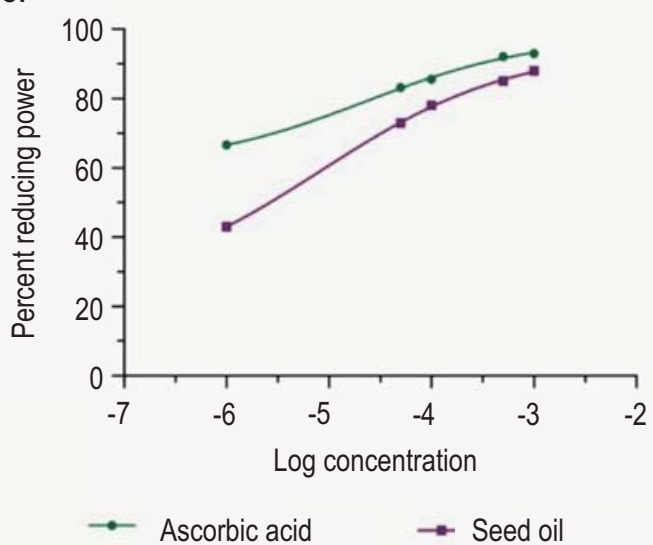

Fig. 1: (A) Log dose response curve of 1,1-diphenyl 2-picrylhyorazyl free radical scavenging activity of seed oil of Datura metal compared with ascorbic acid; (B) Log dose response curve of nitric oxide free radical scavenging activity of seed oil of Datura metal compared with curcumin; (C) Log dose response curve of potassium ferricyanide reducing power of seed oil of Datura metal compared with ascorbic acid bacteria, while fluconazole $(10 \mu \mathrm{g})$ as standard antifungal agent for fungi. Dimethylsulfoxide (10\%) was used as negative control. Mueller-Hinton Agar was used for bacteria while Sabouraud Dextrose Agar was used for fungi. Agar plates were seeded with $100 \mu$ indicator microorganisms (equivalent to $0.5 \mathrm{Mac}$ Farland

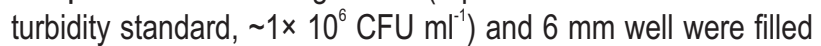
with $100 \mu \mathrm{l}$ of extracts at 250,500, 1000 and $2000 \mathrm{\mu g} \mathrm{ml}^{-1}$ concentrations. The plates were incubated for $24 \mathrm{hrs}$ at $37^{\circ} \mathrm{C}$ for bacteria and $48 \mathrm{hrs}$ at $28^{\circ} \mathrm{C}$ for fungi. The antimicrobial capacity of seed oil was assessed against indicator microorganisms by measuring zone of inhibition around well.

Micro-dilution assay : Minimum inhibitory concentration (MIC) of seed oil was determined by micro-dilution assay as recommended by CLSI M02-A11 and CLSI M27-A2. MuellerHinton broth was used for bacteria, while Sabouraud dextrose broth was used for fungi. The amikacin was used as reference antibiotic for bacteria, while fluconazole as reference antifungal agent for fungi. The seed oil $(500 \mathrm{mg})$ was dissolved in $10 \%$ DMSO (10 ml) to have a stock concentration of $50 \mathrm{mg} \mathrm{ml}^{-1}$. Presterilized 96-well micro-titer plates were used for micro-dilution assay. The serial dilution of seed oil was performed with broth media. Thereafter, $100 \mu \mathrm{l}$ of microbial cell suspension was added to each well. The micro-titer plates were incubated at $37^{\circ}$ for 24 hrs for bacteria and $28^{\circ}$ for $48 \mathrm{hrs}$ for fungi. The minimum inhibitory concentration of seed oil was scored as the lowest concentration giving $100 \%$ growth inhibition.

Statistical analysis : The data on antibacterial and antifungal activities of seed extract of Datura mete/ were examined as mean of three replicates $\pm S D$. The $I_{50}$ values were calculated using four parameters logistic curve (Hill equation) (GraphPad Prism 6.00).

\section{Results and Discussion}

Rai et al. (2013) reported the fatty acid composition of Datura metel seed oil. The major fatty acids were linoleic acid (C18:2) (55.11\%), oleic acid (C18:1) (26.13\%) and a low amount of palmitoleic acid (C16:1) (0.95\%). Fig. 1A shows percent DPPH scavenging of seed oil of Datura metel with increasing concentration in the range of $10-1000 \mu \mathrm{g} \mathrm{ml}^{-1}$. The $\mathrm{IC}_{50}$ of seed oil was $81 \mathrm{~g} \mathrm{~m} \mathrm{~m}^{-1}$, while $\mathrm{IC}_{50}$ of reference ascorbic acid was $18 \mu \mathrm{g} \mathrm{ml}^{-}$ 1. Leaf extract Datura metel in non-polar solvent showed DPPH scavenging potential lower than reference ascorbic acid (Sangeetha et al., 2014). Similarly, seed oil of Malvaceae species viz., such as M. sylvestris, M. sylvestris var. mauritiana and $A$. officinalis extracted with petroleum ether also showed 28-53 times weaker DPPH scavenging activity that butylated hydroxytoluene (Tesevic et al., 2012). The result of the present investigation showing weaker antioxidant activity of seed oil are consistent with those of other studies (Tesevic et al., 2012; Sangeetha et al., 2014) and suggest that polarity of the solvent significantly affect extractable biomolecules. However, when 


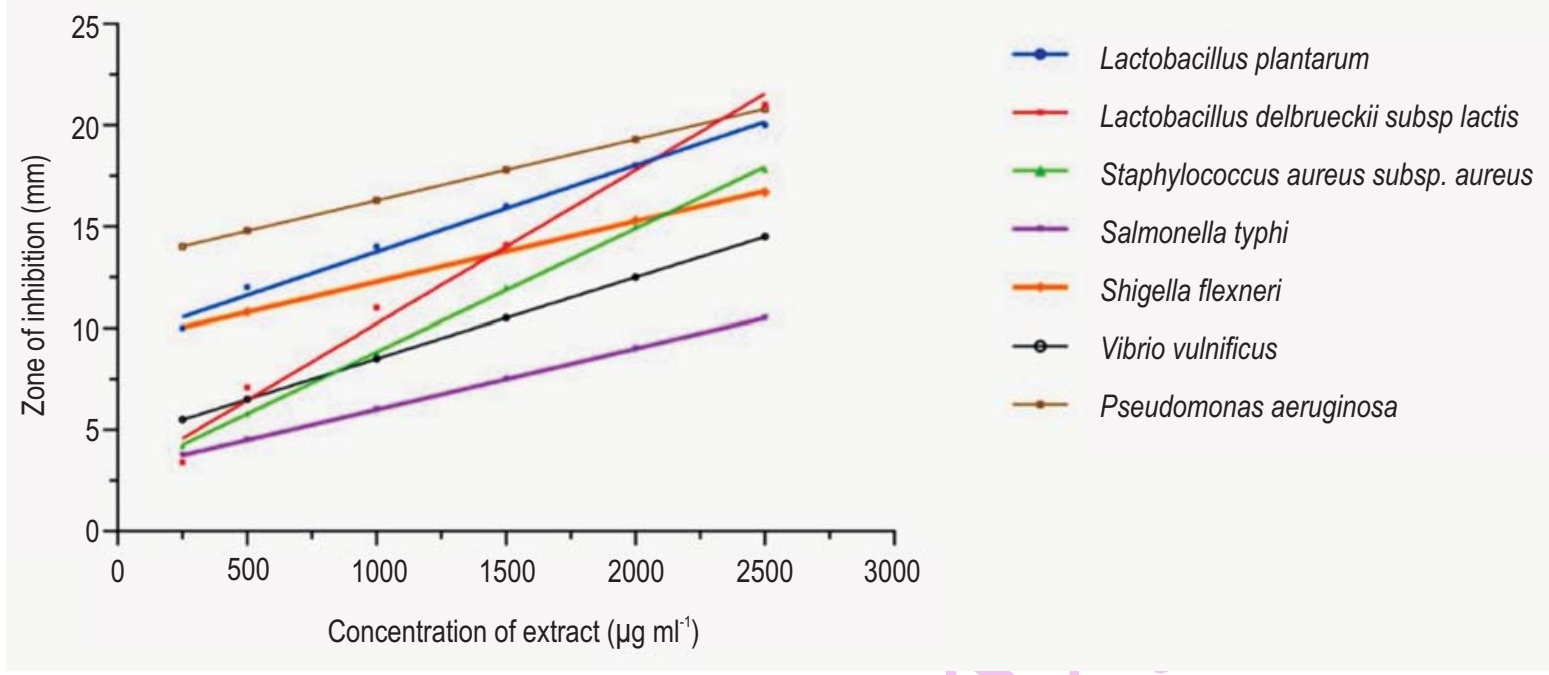

Fig. 2 : Linear regression analysis for susceptibility of different test bacteria correlating with zone of inhibition with increasing concentration of seed oil of Datura metel

Table 1: Antibacterial activities of seed oil of Datura metel and standard antibacterial drug, amikacin against bacterial test organisms

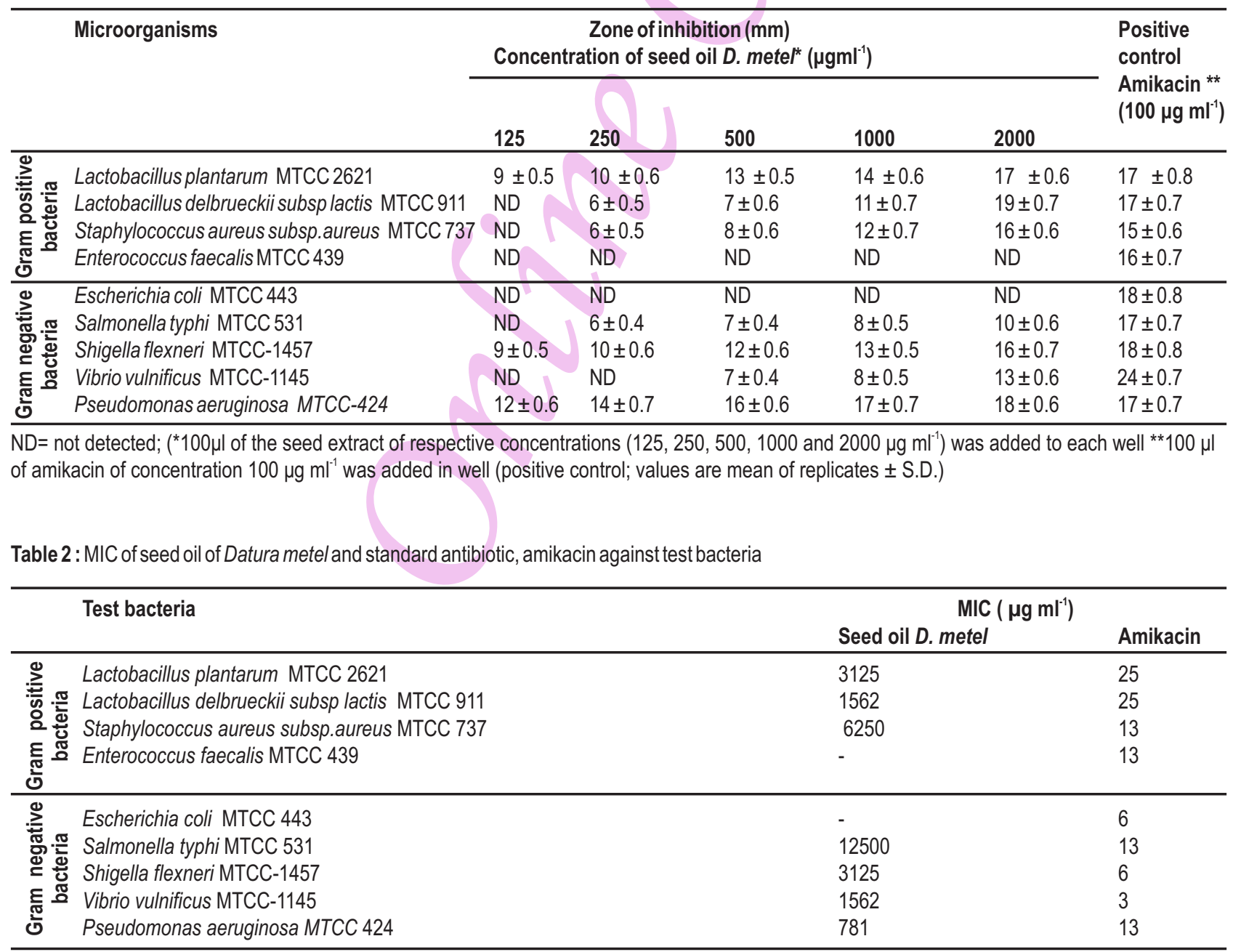


Table 3 : Linear regression equation between zone of inhibition with increasing concentration of seed oil of Datura metel for different bacterial strains

\begin{tabular}{lll}
\hline Bacteria & Regression equation & $\mathbf{R}^{2}$ \\
\hline Lactobacillus plantarum MTCC 2621 & $\mathrm{y}=0.004 \mathrm{x}+9.500$ & 0.9029 \\
Lactobacillus delbrueckii subsp lactis MTCC 911 & $\mathrm{y}=0.007 \mathrm{x}+3.609$ & 0.9954 \\
Staphylococcus aureus subsp.aureus MTCC 737 & $\mathrm{y}=0.006 \mathrm{x}+2.783$ & 0.9739 \\
Salmonellatyphi MTCC 531 & $\mathrm{y}=0.003 \mathrm{x}+3.000$ & 0.9979 \\
Shigella flexneri MTCC-1457 & $\mathrm{y}=0.003 \mathrm{x}+9.292$ & 0.9465 \\
Vibrio vulnificus MTCC-1145 & $\mathrm{y}=0.004 \mathrm{x}+4.500$ & 0.7417 \\
Pseudomonas aeruginosa MTCC 424 & $\mathrm{y}=0.003 \mathrm{x}+13.290$ & \\
\hline
\end{tabular}

Table 4 : Antifungal activity of seed oil of Datura metel and standard antifungal drug, fluconazole against bacterial test organisms

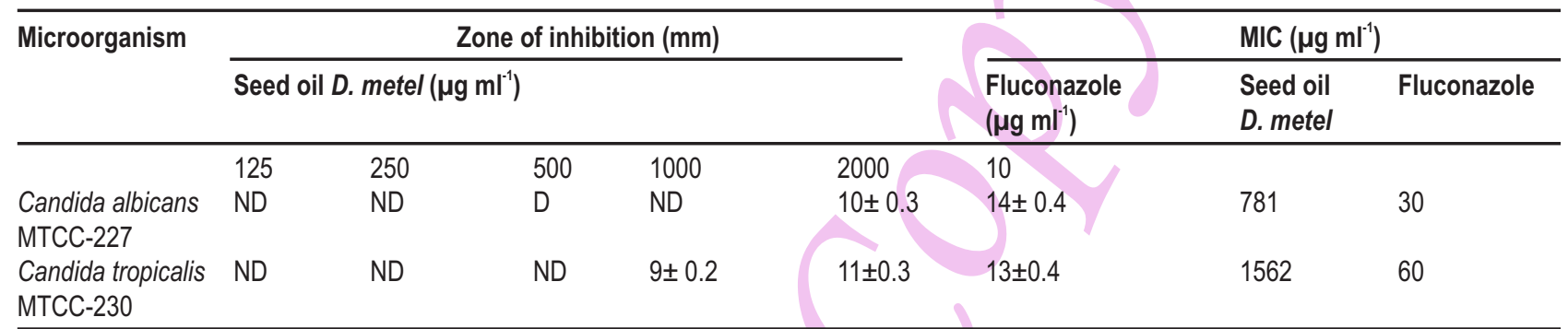

$\mathrm{ND}=$ not detected; ; values are mean of replicates \pm S.D.

polar fractions (mainly polar lipids and phenolics) were found in high levels, extract would have strong radical scavenging activities. The extract obtained in non-polar solvent has weaker antioxidant activity extract obtained in polar solvent. However, these components can act synergistically with primary antioxidants (Ramadan et al., 2009). The DPPH radical scavenging activity of plants oils was highest in $D$. innoxia followed by D. tatula, H. niger, H. muticus, D. metel and least in D. stramonium (Ramadan et al., 2007). Several studies have reported that antioxidant potential of seed oil may be attributed to tocopherols, phytosterols, carotenoids and phenol (Anwar et al., 2008; Cheikh-Rouhou et al., 2008; Nehdi et al., 2010; Jorge et al., 2016).

The effect nitric oxide free radical is stronger when it reacts with superoxide to form peroxynitrite, a potent oxidant with cytotoxic effect. In the present study, seed oil of Datura metel exhibited dose-dependent $\mathrm{NO}$ scavenging activity with $\mathrm{IC}_{50}$ value of $88 \mathrm{gml}^{-1}$, which was at par with standard antioxidant, curcumin $\left(\mathrm{IC}_{50}\right.$ value $\left.80 \mathrm{\mu g} \mathrm{ml}^{-1}\right)$ (Fig. 2B). Previous study suggest that tocopherols, in addition to their chain breaking abilities, react with nitric oxide and protect against peroxynitrite (Joseph et al., 2009) and other reactive nitrogen species formation. Excess production of nitric oxide is implicated in several physiological and pathological processes (Förstermann and Sessa, 2012). The radical scavenging activities of the antioxidant may assist in protecting lipid membranes from attack by nitric oxide/peroxynitrite. In the study, it is implicated that seed oil antioxidants of Datura metel might compete with oxygen and inhibit generation of peroxynitrite.

In addition, seed oil has effective reducing power, $\mathrm{IC}_{50} 8$ $\mu \mathrm{g} \mathrm{ml}^{-1}$ which was lower than reference ascorbic acid $\left(\mathrm{IC}_{50} 22 \mu \mathrm{g}\right.$ $\left.\mathrm{ml}^{-1}\right)$ (Fig. 1C). The results of the study (Fig. 1C) revealed that seed oil of Datura metel has concentration-dependent response towards $\mathrm{Fe}^{3+}$ reducing power. Thus, seed oil of Datura metel can reduce ferric ion to ferrous ion by donating an electron.

In the present study, it was found that seed oil of Datura metel possessed antibacterial efficacy at least against seven bacterial strains tested, with zone of inhibition 6-19 mm (for reference amikacin 6-19 mm, at $1000 \mathrm{mg} \mathrm{ml}^{-1}$ ) (Table 1) and MIC 781-12500 $\mathrm{g} \mathrm{mll}^{-1}$ (for reference amikacin MIC 3-25 $\mathrm{g} \mathrm{m} \mathrm{ml}^{-1}$ ) (Table 2). The highest zone of inhibition and lowest minimum inhibitory concentration (MIC) was recorded against Lactobacillus delbrueckii subsp lactis MTCC $911(19 \mathrm{~mm})$ and Pseudomonas aeruginosa $(18 \mathrm{~mm})$ indicating susceptibility of strains to seed oil of Datura metel. The results of antibacterial study (Fig. 2) showed concentration-dependent response, the zone of inhibition increased with the increase in the concentration of seed oil. Linear regression equation with zone of inhibition with increasing concentration of seed oil is shown in Table 3. It is interesting to note that seed oil from this plant also sensitizes $S$. aureus, a strain commonly associated with the development of methicillin resistance. Okwu and Igara (2009) isolated a steroidal compound, 5', 7' dimethyl 6' hydroxyl amine -yne sitosterol from ethanolic extract of leaf of Datura metel that showed antibacterial potential against $S$. aureus, $P$. aeruginosa, Proteus mirabis, $S$. typhi, B. subtilis and $K$. pneumonae but the compound could not 
inhibit $E$. coli. In an another investigation, Okwu and Igara (2011) isolated a new $\beta$-carboline alkaloid (1, 7 dihydroxy-1-methyl 6, 8 dimethoxy $\beta$-carboline) from $D$. metel leaves that showed antagonistic effect against $P$. aeruginosa, $K$. pneumonia, $S$. aureus, P. mirabilis, E. coli, B. subtilis and S. typhi. Various studies suggest that antimicrobial potential of extract is dependent on several factors such as the method of extraction, polarity of solvent, hydrophobicity of compounds, types of microorganisms and difference in the structure of outer membrane and antibiotic resistance pattern of test microorganisms (Bacon et al., 2016; Ortega-Ortega et al., 2017). Several reports are available that indicate the antibacterial capacity of Datura metal extract against bacteria (Sakthi et al., 2011; Vadlapudi and Kaladhar, 2012; Gachande and Khillare, 2013). However, only few studies have reported characterization of phytocompounds. In addition to antibacterial activity, seed oil of Datura metel also showed high antifungal potential against Candida albicans MTCC 227 (zone of inhibition $10 \mathrm{~mm}^{2} 2000 \mathrm{\mu g} \mathrm{ml}^{-1}$ of seed oil) and Candida tropicalis MTCC 230 (zone of inhibition $11 \mathrm{~mm}^{2} 2000 \mathrm{\mu g} \mathrm{m}^{-1}$ of seed oil), which is comparable to the standard antifungal agent fluconazole $\left(10 \mu \mathrm{g} \mathrm{ml}^{-1}\right)$ (Table 4). The MICs of seed oil for Candida albicans MTCC 227 and Candida tropicalis MTCC 230 was $781 \mu \mathrm{g} \mathrm{ml}^{-1}$ and $1562 \mu \mathrm{g} \mathrm{ml}^{-1}$, which was higher than fluconazole. The results based on MICs indicated that, although seed oil had anti-candidal activity but was less potent than standard antifungal agent, fluconazole (Table 4). Besides anti-candidal activity, few reports indicate antifungal activity of Datura metel extract against Aspergillus sp. (Dabur et al., 2004; Fakai et al., 2016). It is reported that chloroform fraction of $D$. metel exhibited antifungal efficacy against $A$ spergillus sp. viz., A. fumigatus, $A$. flavus and $A$. niger but efficacy of extract was less than broad spectrum polyene antifungal agent, amphotericin B (Sharma, 2002). In a further investigation on leaf extract of Datura metel, Dabur et al. (2004) isolated a new pyrrole derivative, 2 beta-(3,4-dimethyl2,5-dihydro-1H-pyrrol-2-yl)-1'-methylethyl pentanoate showing antifungal activity against $A$ spergillus fumigatus.

The findings suggest that seed oil of Datura metel exhibited antioxidant and antimicrobial potential. However, the weak antioxidant activity of the extract in comparison with reference may be due to low content of polyphenol in the oil. Several reports have attributed the antioxidant potential of seed oil due to tocopherols and phenolic compounds (Frankel, 1996; Sakai et al., 2010). The study also showed significant antibacterial and anti-candidial activities of seed oil. The secondary metabolites such as glycosides, alkaloids, steroids, flavonoids and tannins may contribute towards antimicrobial activity of seed oil of Datura metel.

\section{Acknowledgments}

The authors are thankful to the Graphic Era University, Dehradun, Uttarakhand and Doon P.G. Paramedical College, Dehradun, Uttarakhand, India.

\section{References}

Alabri, T.H.A., A.H.S. Al Musalami, M.A. Hossain, A.M. Weli and Q. AlRiyami: Comparative study of phytochemical screening, antioxidant and antimicrobial capacities of fresh and dry leaves crude plant extracts of Datura metelL. J. King Saud. Univ. Sci.,26, 237 (2014).

Alebiowu, G., M.N. Femi-Oyewo, A.A. Elujoba and O.S. Ojo: Toxicity studies on Datura metel $L$. with reference to Official stramonium. J. Herb. Pharmacother., 7, 1-12(2007).

Akharaiyi, F.C.: Antibacterial, phytochemical and antioxidant activities of Datura metel. Int. J.Chem. Tech. Res., 3, 478-483 (2011).

Anwar, F., R. Naseer, M.I. Bhanger, S. Ashraf, F.N. Talpur and F.A. Aladedunye: Physico-chemical characteristics of citrus seeds and seed oils from Pakistan. J. Am. Oil. Chem. Soc., 85, 321-330 (2008).

Atanasov, A.G., B. Waltenberger, E.M. Pferschy-Wenzig T. Linder, C. Wawrosch, P. Uhrin, V. Temml, L. Wang, S. Schwaiger, E.H. Heiss and J.M. Rollinger: Discovery and resupply of pharmacologically active plant-derived natural products: A review. Biotechnol. Adv.,33, 1582-1614 (2015).

Bacon, K., R. Boyer, C. Denbow, S. O'Keefe, A. Neilson and R. Williams: Evaluation of different solvents to extract antibacterial compounds from Jalapeño peppers. Food Sci. Nutr., 5, 1-7 (2016).

Bellila, A., C. Tremblay, A. Pichette, B. Marzouk, V. Mshvildadze, S. Lavoie and J. Legault: Cytotoxic activity of withanolides isolated from Tunisian Datura metel L. Phytochemistry,72, 3031 (2011).

Borjian, B.M., A. Goli and M. Gharachourloo: Effect of roasted sesame oil on qualitative properties of frying oil during deep-fat frying. $\mathrm{J}$. Agricul. Sci. Technol., 18, 1531-1542 (2016).

Cervantes-Cardoza, V., N. E. Rocha-Guzmán, J. A. Gallego-Infante, M. Rosales-Castro, L. Medina-Torres and R. F. González-Laredo: Actividad antioxidante de extractos de semilla de tres variedades de manzana (Malus domestica Borkh -Rosaceae). Boletín Latinoamericano y del Caribe de Plantas Medicinales y Aromáticas, 9, 446-456 (2010).

Cheikh-Rouhou, S., S. Besbes, G. Lognay, C. Blecker, C. Deroanne and H. Attia: Sterol composition of black cumin (Nigella sativa L.) and Aleppo pine (Pinus halepensis Mill.) seed oils. J. Food Comp. Anal., 21, 162-168 (2008).

CLSI (Clinical and Laboratory Standards Institute): Performance standards for antimicrobial disk susceptibility tests; Approved Standard $11^{\text {th }}$ Edu., CLSI document M02-A11 (2012).

CLSI (Clinical and Laboratory Standards Institute): M2-A7 Performance standards for antimicrobial disk susceptibility tests; Approved Standard-Seventh Edition (2000).

Cuendet, M., K. Hostettmann, O. Potterat and W. Dyatmiko: Iridoid glucosides with free radical scavenging properties from Fagraea blumei. Helv. Chim. Acta., 80, 1144-52 (1997).

Dabur, R., A.K. Chhillar, V. Yadav, P.K. Kamal, J. Gupta and G.L. Sharma: In vitro antifungal activity of 2-(3,4-dimethyl-2,5-dihydro-1 H-pyrrol2-YI)-1-methylethyl pentanoate, a dihydropyrrole derivative. J. Med. Microbiol.,54, 549-52 (2005).

Dabur, R., M. Ali, H. Singh, J. Gupta and G. L. Sharma:A novel antifungal pyrrole derivative from Datura metel leaves. Die Pharmazie,59, 568-70 (2004).

Donatus, E.O. and C.I. Ephraim: Isolation, characterization and antibacterial activity of alkaloid from Datura metel L. leaves. Afr. J. 
Pharm. Pharmacol., 3, 277-281 (2009).

Duke, J.A. and E.S. Ayensu: Medicinal plants of China. Houghton Mifflin China, pp. 90-91 (1985).

Forstermann, U. and W.C. Sessa: Nitric oxide synthases: Regulation and function. Eur. Heart J., 33, 837a-837d (2012).

Frankel, E., S. Huang, R. Aeschbach and E. Prior: Antioxidant activity of rosemary extract and its constituents, carnosic acid, carnosol, and rosmarinic acid in bulk oil and oil-in-water emulsion. J. Agric. Food Chem., 44, 131-135 (1996).

Gachande, B.D. and E.M. Khillare: In vitro evaluation of Datura species for potential antimicrobial activity. Biosci. Discov.,4, 78-81 (2013).

Gaire, B.P. and L. Subedi: A review on the pharmacological and toxicological aspects of Datura stramonium L. J. Integr. Med.,11, 73-79 (2013).

Garavaglia, J., M.M. Markoski, A. Oliveira and A. Marcadenti: Grape seed oil compounds: Biological and chemical actions for health. Nutrition and Metabolic Insights, 9, 59 (2016).

Garratt, D.C.: The quantitative analysis of drugs. Vol. 3. Chapman and Hall Ltd., Japan, pp. 456-4589 (1964).

Hussain, A. I., F. Anwar, S. T. H. Sherazi and R. Przybylski: Chemical composition, antioxidant and antimicrobial activities of basil (Ocimum basilicum) essential oils depends on seasonal variations. Food Chem., 108, 986-995, (2008).

Hossain, M.A., M.S.A.A. Kalbani, S.A.J.A.F. Farsi, A.M. Weli and Q. AlRiyami: Comparative study of total phenolics, flavonoids contents and evaluation of antioxidant and antimicrobial activities of different polarities fruits crude extracts of Datura metel L. Asian Pac. J. Trop. Dis., 4, 378-383 (2014).

Jorge, N., A.C.D. Silva and C.P. Aranha: Antioxidant activity of oils extracted from orange (Citrus sinensis) seeds. An. Acad. Bras. Ciênc., 88,951-958 (2016).

Joseph, S., B. Sabulal, V. George, T.P. Smina and K.K. Janardhanan: Antioxidative and anti-inflammatory activities of the chloroform extract of Ganoderma lucidum found in South India. Sci. Pharm., 77, 111-121 (2009).

Marcocci, L., J.J. Maguire, M.T. Droylefaix and L. Packer: The nitric oxide-scavenging properties of Ginkgo biloba extract EGb 761. Biochem. Biophys. Res. Commun., 201, 748-755 (1994).

Maheshwari, N.O., A. Khan and B.A. Chopade: Rediscovering the medicinal properties of Datura sp.: A review. J. Med. Plants Res., 7, 2885-2897 (2013).

Mann, J. : Murder, magic and medicine. Oxford University Press, Oxford, pp. 82-84 (1996).

Nair, M. K. M., P. Vasudevan and K. Venkitanarayanan: Antibacterial effect of black seed oil on Listeria monocytogenes. Food Control, 16, 395-398 (2005).

Nawirska-Olszańska, A., A. Kita, A. Biesiada, A. Sokól-Łętowska and A. Z. Kucharska: Characteristics of antioxidant activity and composition of pumpkin seed oils in 12 cultivars. Food Chem., 139, 155-161(2013).

Nehdi, I., S. Omri, M.I. Khalil and S.I. Al-Resayes: Characteristics and chemical composition of date palm (Phoenix canariensis) seeds and seed oil. Ind. Crop Prod., 32, 360-365 (2010).

Okwu, D.E. : Isolation, characterization and antibacterial activity screening of a new $\beta$-carboline alkaloid from Datura metel L. Der. Chemica Sinica, 2, 261-67 (2011).

Okwu, D.E. and E.C. Igara: Isolation, characterization and antibacterial activity of alkaloid from Datura metel L. leaves. Afr. J. Pharm. Pharmacol.,3, 277-81 (2009).
Ortega-Ortega, M.D.L.A., N.D.S. Cruz-Cansino, E. Alanís-García, L. Delgado-Olivares, J.A. Ariza-Ortega, E. Ramírez-Moreno and J.D.J. Manríquez-Torres: Optimization of ultrasound extraction of cactus pear (Opuntia ficus indica) seed oil based on antioxidant activity and evaluation of its antimicrobial activity. J. Food Qual., doi.org/10.1155/2017/9315360,1-9 (2017).

Oyaizu, M. : Studies on products of browning reactions: Antioxidant activities of products of browning reaction prepared from glucose amine. Jap. J. Nutr.,44, 307-315(1986.).

Ozcan, B., M. Esen, M.K. Sangun, A. Coleri and M. Caliskan: Effective antibacterial and antioxidant properties of methanolic extrac of Laururs nobillis seed oil. J. Env. Biol., 31, 637-641, (2010).

Pawar, H.A., A.V. Shenoy, P.D. Narawade, P.Y. Soni, P.P. Shanbhag and V.A. Rajal: Preservatives from nature: A review. Int. J. Pharm. Phytopharm. Res., 1, 78-88 (2017).

Rai, I., R.K. Bachheti and A. Joshi: Chemical composition, mineral and nutritional value of Datura metel seed. Int. J. Pharm. Bio. Sci.,4, 429-36 (2013).

Rajesh, G.L. Sharma: Studies on antimycotic properties of Datura metel. J. Ethnopharmacol., 80, 193 (2002).

Ramadan, M.F., S.G. Kinni, L.N. Rajanna, Y.N. Seetharam, M. Seshagiri and M. Jörg-Thomas : Fatty acids, bioactive lipids and radical scavenging activity of Celastrus paniculatus Wild. seed oil. Sci. Hort., 123, 104-9 (2009).

Rigacci, S. and M. Stefani: Nutraceutical properties of olive oil polyphenols. An Itinerary from cultured cells through animal models to humans. (Eds.: A. Segura-Carretero and A.M. Gómez Caravaca). Int. J. Molec. Sci., 17, 843 (2016).

Roy, S., S. Pawar and A. Chowdhary: Evaluation of in vitro cytotoxic and antioxidant activity of Datura metel L. and Cynodon dactylon L. extracts. Pharmaco. Res., 8, 123-127 (2016).

Sajid, Z.I., F. Anwar, G. Shabir, G. Rasul, K.M. Alkharfy and A.H. Gilani: Antioxidant, antimicrobial properties and phenolics of different solvent extracts from bark, leaves and seeds of Pongamia pinnata (L.) Pierre. Molecules, 17, 3917-3932 (2012).

Sakai, K., S. Kino, M. Takeuchi, T. Ochi, G.D. Cruz and I. Tomita: Analysis of antioxidant activities in vegetable oils and fat soluble vitamins and biofactors by the PAO-SO method. Methods Mol. Biol., (Clifton, N.J.), 594, 241-50 (2010).

Sakthi, S., P. Saranraj and M. Geetha: Antibacterial evaluation and phytochemical screening of Datura metel leaf extracts against bacterial pathogens. Int. J. Pharm. Biol. Arch., 2, 1130-1136 (2011).

Sangeetha, S., M. Deepa, N.Sugitha, S. Mythili and A. Sathiavelu: Antioxidant activity and phytochemical analysis of Datura metel. Int. J. Drug Dev. Res., 6, 280-85 (2014).

Tešević, V., V. Vajs, S. Lekić, I. Đorđević, M. Novaković, L. Vujisić and M. Todosijević: Lipid composition and antioxidant activities of the seed oil from three Malvaceae species. Arch. Biol. Sci. Belgrade, 64, 221-27 (2012).

Tian, H.L., P. Zhan and K.X. Li: Analysis of components and study on antioxidant and antimicrobial activities of oil in apple seeds. Int.J. Food Sci. Nutr., 61, 395-403 (2010).

Vadlapudi, V. and D. Kaladhar: Antimicrobial study of plant extracts of Datura metel $\mathrm{L}$. against some important disease causing pathogens. Asian Pac. J. Trop. Dis., 2, S94-S97 (2012).

Yang, B.Y., Y.G. Xia, Y. Liu, L. Li, H. Jiang, L. Yang, Q.H. Wang and H.X. Kuang: New antiproliferative and immunosuppressive withanolides from the seeds of Datura metel . Phytochem. Lett., 8 , 92 (2014). 